\title{
Histological evaluation and E-cadherin and $\beta$-catenin expression in kidney of dogs submitted to renal ischemia and reperfusion after chlorpromazine administration
}

[Avaliação histológica e imunomarcação de E-caderina e $\beta$-catenina em rins de cães submetidos a isquemia e referfusão renal após administração de clorpromazina]

L.B. Menezes, M.C.S. Fioravanti, F.A. Oliveira, M.S.B. Silva, L.G. Franco, T.P. Sales, M.M. Andrascko, L.L.B. Guimarães, M.P. Miguel, E.G. Araújo

Universidade Federal de Goiás - Goiânia, GO

\begin{abstract}
Renal ischemia can be associated with some urological procedures, such as renovascular surgery or kidney transplantation, that are often followed by acute renal failure. The aim of this study was to verify the E-cadherin and $\beta$-catenin localization in canine kidney in different times of renal ischemia and reperfusion after chlorpromazine application. Twelve dogs were randomly distributed equally into two groups. GroupA with ischemia and reperfusion without chlorpromazine and groupB with ischemia and reperfusion treated by chlorpromazine. GroupB received intravenous chlorpromazine, 15 min before the artery obstruction, which lasted 1 hour. After this period, the clamps in the renal arteries were released and the organ remained in reperfusion for 2 hours. In each group, anti-E-cadherin and anti- $\beta$-catenin antibodies were made in six tissue samples from renal parenchyma. E-cadherin and $\beta$-catenin are differentially expressed in segments from cortex and medulla in dog's kidneys and the use of chlorpromazine did not alter the expression of both proteins. Occlusion of the left renal artery in dogs causes morphological alterations mainly in proximal convoluted tubules, beginning $30 \mathrm{~min}$ after the start of ischemia and being aggravated after two hours of reperfusion. These results reveal that chlorpromazine did not change kidneys' histological aspect nor E-cadherin and $\beta$-catenin expression.
\end{abstract}

Keywords: acute renal failure, adherens junctions, cell adhesion, kidney tubular necrosis

\section{RESUMO}

A lesão renal isquêmica pode estar associada a procedimentos urológicos, tais como cirurgia renovascular, cirurgia renal extracorpórea ou transplante renal. Essa injúria, muitas vezes, é seguida de insuficiência renal aguda. O objetivo deste trabalho foi observar a localização da E-caderina e da $\beta$ catenina em rim de cães, além de relacionar a expressão dessas proteinas das junções de aderência em diferentes tempos de isquemia e reperfusão com ou sem a aplicação de clorpromazina. Para tanto, foram utilizados 12 cães, distribuidos aleatoriamente em dois grupos de seis indivíduos: grupo A, com isquemia e reperfusão sem tratamento por clorpromazina, e o grupo $B$, com isquemia e reperfusão tratado por clorpromazina. No procedimento cirúrgico, foi realizada uma incisão paracostal esquerda para identificação e isolamento do rim esquerdo e da artéria renal esquerda. Após o isolamento da artéria, os animais de todos os grupos tiveram o vaso ocluído. Os animais do grupo B receberam clorpromazina via endovenosa, na dose de $5 \mathrm{mg} / \mathrm{kg}$, $15 \mathrm{~min}$ antes da clampagem do vaso, que durou uma hora. Após este periodo, as artérias renais foram desobstruidas e os órgãos permaneceram em reperfusão por duas horas. Em cada grupo, foram extraídas seis amostras de parênquima renal, com utilização de agulha trucut, para marcação com anticorpos anti-E-caderina e anti- $\beta$-catenina por meio de imunoistoquimica. Ecaderina e $\beta$-catenina são diferencialmente expressas em segmentos do córtex e da medula em rim de cães e o uso da clorpromazina não alterou a expressão das duas proteínas.

Palavras-chave: insuficiência renal aguda, junções de aderências, adesão celular, necrose tubular renal

Recebido em 2 de dezembro de 2016

Aceito em 31 de janeiro de 2017

E-mail: lilianabmleite@gmail.com 


\section{INTRODUCTION}

Ischemic renal injury may be linked to urological procedures such as revascular surgery, extracorporeal renal surgery or renal transplant. This type of injury is often followed by acute renal failure (Huan and Adelsberg, 1999). Ischemia and subsequent reperfusion/reoxygenation change the epithelial function by disrupting intercellular junctions. Functions of epithelial cells depend on the integrity of intercellular junctions as well as on the lipid-protein arrangement in the plasma membrane, which is closely surrounded by apical and basolateral domains (Tsuji et al., 1993). Studies have shown that a variety of cadherins are present in the kidney and are expressed differently in several nephron segments (Balzac et al., 2005).

Ischemia induces various biochemical injuries in adherens junctions (Bush et al., 2000b). An ischemic injury results in E-cadherin's selective degradation and in the disruption of proteinprotein interaction between E-cadherin and catenins, which jeopardizes junctions. Such findings suggest that changes in E-cadherin and in its interactions with cytoplasmic components of adherens junctions constitute an injury mechanism in epithelial ischemia.

The depletion of ATP in renal epithelial cells leads to fast E-cadherin interiorization. Prolonged ischemic injury leads not only to Ecadherin interiorization but also to site-specific protein breakdown and to the disruption of cadherin-catenin interaction. The degradation of E-cadherin as well as the interruption of the cadherin-catenin interaction probably constitutes a critical injury in epithelial ischemia (Tsuji et al., 1993).

Pharmacological interventions in these processes show great potential to improve clinical conditions in surgeries involving ischemia and reperfusion (Zuhorn et al., 2007). A recently studied option is chlorpromazine, a low-cost, pre-anesthetic drug whose protection has not yet been fully explained (Joeschke, 2003; Schrier et al., 2004).
The aim of this study was to describe E-cadherin and $\beta$-catenine distribution in canine kidneys as well as to assess it in various periods of renal ischemia and reperfusion after administering chlorpromazine.

\section{MATERIALS AND METHODS}

The project was approved by the Research Ethics Committee of Federal University of Goias (006/2008). This experiment analyzed 12 male dogs, adult, of non-specific breed. Prior to the experiment the dogs were clinically assessed to identify systemic and renal infirmities that might interfere with results. Urine and blood samples were collected for hemogram testing and a hematozoa research was performed to confirm organic health conditions. The dogs were divided in two groups of six: GroupA: renal ischemia and reperfusion and GroupB: renal ischemia and reperfusion medicated with chlorpromazine.

The animals underwent anesthetic induction by intravenous propofol application and anesthetic maintenance with halothane. After a left paracostal incision the left kidney and the left renal artery were isolated and arterial occlusion via Satinsky tweezers was performed. Chlorpromazine was administered intravenously to groupB animals in a dose of $5 \mathrm{mg} / \mathrm{kg}, 15 \mathrm{~min}$ before arterial clipping, which lasted for one hour. Following this period renal arteries were unobstructed and six samples of renal parenchyma from the left kidney's convex side were collected in each group via a soft tissue biopsy needle (Tru-cut $\left.{ }^{\circledR}\right)$ for histological and immunohistochemical assessment during the first two hours of reperfusion. The first sample was collect after 15 minutes $\left(\mathrm{I}_{0}\right)$ chlorpromazine application prior to ischemia. During the 60 minutes of ischemia, the samples were obtained after 5 minutes $\left(\mathrm{I}_{5}\right), 30$ minutes $\left(\mathrm{I}_{30}\right)$ and, during the 120 minutes of reperfusion the samples were collect at 5 minutes $\left(R_{5}\right), 30$ minutes $\left(R_{30}\right)$ and, 120 minutes $\left(\mathrm{R}_{120}\right)$.

In the histological exam, a descriptive and semiquantitative analysis was carried out; the former included renal glomerular, tubular, and interstitial compartments (Chien et al., 1977). 
The exam assessed the possible presence of acute lesions. Each parameter was assessed blindly; cortical and medullary compartments of all fragments were analyzed via a 400x increase. Quantification was performed with scores
(Table 1). Results were expressed as interstitial injury index and tubular injury index (Takito et al., 2005) (Table 2). Mann-Whitney test and Kruskal-Wallis analysis of variance by ranks were applied to the statistical analysis.

Table 1. Interpretation of scores applied to the analysis of histopathological parameters in kidneys of dogs submitted to renal ischemia and reperfusion

\begin{tabular}{|c|c|c|c|}
\hline Location & $\begin{array}{l}\text { Histopathological } \\
\text { alteration }\end{array}$ & Scores & Meaning \\
\hline \multirow{2}{*}{ Glomerulus } & Inflammatory infiltrate & 0 & Absence of alteration \\
\hline & Degeneration/Necrosis & 1 & Presence of alteration \\
\hline \multirow{4}{*}{$\begin{array}{l}\text { Tubular } \\
\text { Compartment }\end{array}$} & \multirow{4}{*}{$\begin{array}{l}\text { Hydropic degeneration } \\
\text { Nuclear changes } \\
\text { Desquamation }\end{array}$} & 0 & Absence of alteration \\
\hline & & 1 & Alteration in less than $25 \%$ of tubular cells \\
\hline & & 2 & Alteration in $26 \%$ to $50 \%$ of tubular cells \\
\hline & & 3 & Alteration in $51 \%$ to $100 \%$ of tubular cells \\
\hline & Edema & 0 & Absence of alteration \\
\hline Interstitial & Congestion & 1 & Alteration in less than $25 \%$ of areas assessed \\
\hline \multirow{2}{*}{ Compartment } & Hemorrhage & 2 & Alteration in $26 \%$ to $50 \%$ of areas assessed \\
\hline & Inflammation & 3 & Alteration in $51 \%$ to $100 \%$ of areas assessed \\
\hline
\end{tabular}

Table 2. Values given to different histopathological changes found in kidneys of dogs submitted to renal ischemia and reperfusion

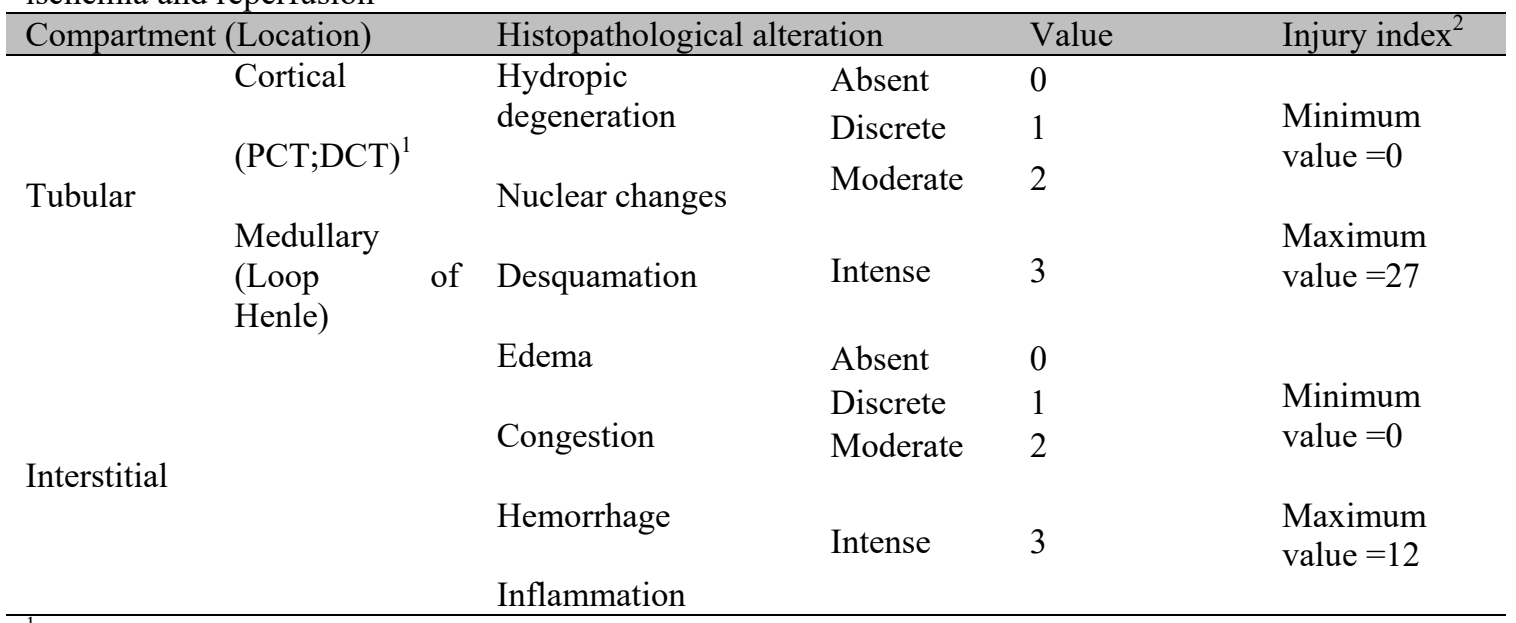

${ }^{1} \mathrm{PCT}=$ proximal convoluted tubule; $\mathrm{DCT}=$ distal convoluted tubule

${ }^{2}$ compartment number $\mathrm{x}$ alteration number $\mathrm{x}$ attributed value

Kidney $3 \mu \mathrm{m}$ sections were stained with anti-Ecadherin (purified mouse, BD Biosciences) $1: 2000(\mathrm{v} / \mathrm{v})$ and anti- $\beta$-catenin (purified mouse, BD Biosciences) 1:1000 (v/v) antibodies. A 2N citrate solution (ph 6,0) was subsequently placed in a water bath for $30 \mathrm{~min}$ at $95^{\circ} \mathrm{C}$ for antigen recovery. Tissues were incubated overnight in a humid chamber at $4^{\circ} \mathrm{C}$ with primary antibodies. Sections were washed several times in PBS and incubated at room temperature for $30 \mathrm{~min}$ with Envision (Dako), then washed in PBS. The reaction was revealed by a diaminobenzidine peroxidase solution (Liquid DAB Substrate Chromogen System $^{\circledR}$, Dako) for 3 min. Sections were counterstained with Mayer's hematoxylin for 30 seconds.

The slides were analyzed via light microscopy regarding staining location and tone; the staining was measured by a semiquantitative assessment that attributed scores (absence, discrete, moderate or intense staining) (Tab. 3). 
Table 3. Scores applied to staining analysis of E-cadherin and $\beta$-catenin antibodies in kidneys of dogs

\begin{tabular}{|l|l|}
\hline Staining & Score \\
\hline & 0 (Absence of staining) \\
\hline & 1 (Discrete staining) \\
\hline & 2 (Moderate staining) \\
\hline & \\
\hline
\end{tabular}

\section{RESULTS}

The morphological changes were similar in both groups for the various periods. Kidney fragments showed an almost normal, preserved histological aspect in I0. No changes in glomeruli were observed throughout the experiment.

In regards to PCT, discrete hydropic degeneration and desquamation were observed in $\mathrm{I}_{5}$ and $\mathrm{I}_{30}$, which became moderate in $\mathrm{R}_{5}$ and $\mathrm{R}_{30}$ and intense in the final sample collection $\left(\mathrm{R}_{120}\right)$. The presence of protein material in PCT's intraluminal protein in $\mathrm{I}_{30}$ and $\mathrm{R}_{5}$ was registered. As for DCT, hydropic degeneration and desquamation were found only from $\mathrm{R}_{5}$ onwards in discrete and moderate intensity, but such factors were intense at the end of reperfusion $\left(\mathrm{R}_{120}\right)$ (Figure 1a, b,c,d).

Alterations compatible with tubular necrosis (cytoplasmic acidophilia and picnosis) were found in a few tubular cells at the last moment $\left(\mathrm{R}_{120}\right)$ in both groups. Alterations were not observed in nephron medullary components, except for the presence of cell debris from $\mathrm{R}_{5}$ onwards. Discrete congestion was observed in the interstitial compartment in $\mathrm{I}_{5}$ and was intensified after $30 \mathrm{~min}$ of ischemia $\left(\mathrm{I}_{30}\right)$. Interstitial inflammatory cells were observed only in a discrete form in rare microscopy fields and only at the end of reperfusion $\left(\mathrm{R}_{120}\right)$. Indices of renal injuries (Figure 2), which reveals similar behavior in the two groups i.e. injuries were intensified due to ischemia/reperfusion.

There were no significant differences between the two groups at any of the periods assessed $(\mathrm{P}>0,05)$. However, significant differences $(\mathrm{P}<0,05)$ were detected among all periods $\left(\mathrm{I}_{0}, \mathrm{I}_{5}\right.$, $\mathrm{I}_{30}, \mathrm{R}_{5}, \mathrm{R}_{30}$ ) in both groups at the end of reperfusion $\left(R_{120}\right)$.

Fragments stained with $\beta$-catenin antibody revealed similar staining in both groups as regards the protein's location in the kidney; it was positive in proximal and distal convoluted tubules, in all medullary components, in the collecting duct (CD), and in thick (TkLH) and thin (TLH) loops of Henle. Such staining was not detected in glomeruli.

Intensity variation in this protein's staining on animals was reported at all biopsy moments and in both groups. Absence of staining in glomeruli was observed in all samples. Staining was discrete in proximal convoluted tubules; around $30 \%$ to $90 \%$ of tubules showed absence of staining throughout all sampling moments. Staining varied from moderate to intense in distal convoluted tubules. 
(a)

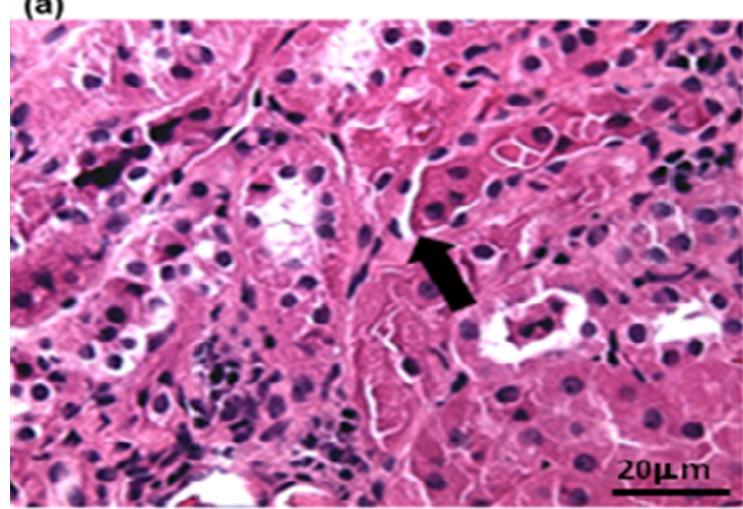

\section{(c)}

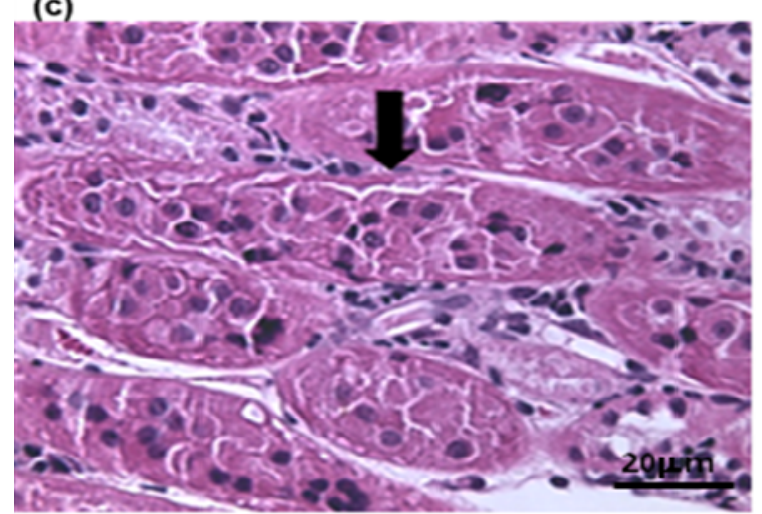

(b)

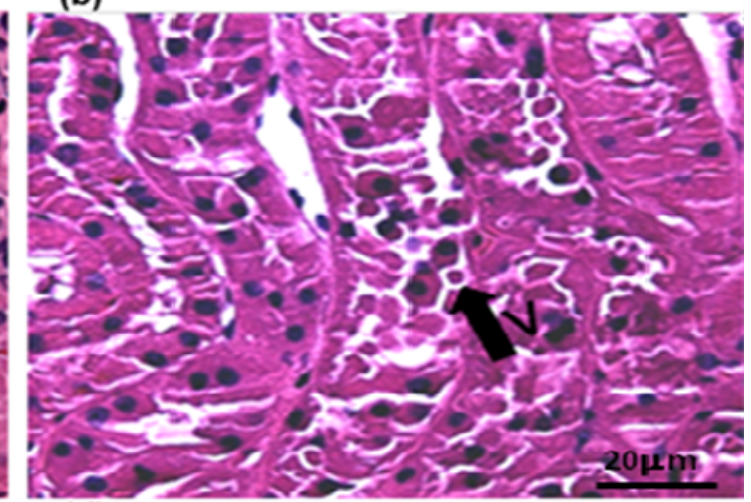

(d)

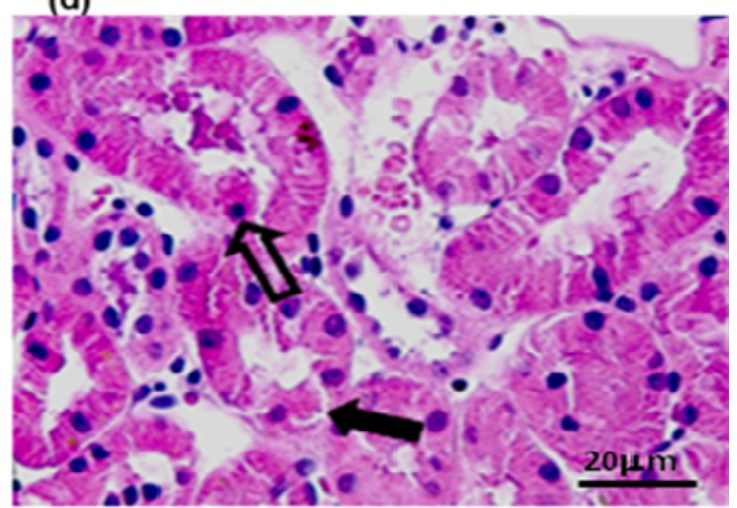

Figure 1. Photomicrographies of the renal cortical region of dogs submitted to ischemia and reperfusion (H\&E stain; scale bars indicated $400 \mu \mathrm{m}$ ), showing tubular cell desquamation (black arrow) after 30 min of ischemia, which was intensified after reperfusion. (a) $\mathrm{I}^{30}$ of GroupA; (b) $\mathrm{R}^{120}$ of GroupA; (c) $\mathrm{I}^{30}$ of GroupB; (d) $\mathrm{R}^{120}$ of GroupB, showing picnosis (open arrow).

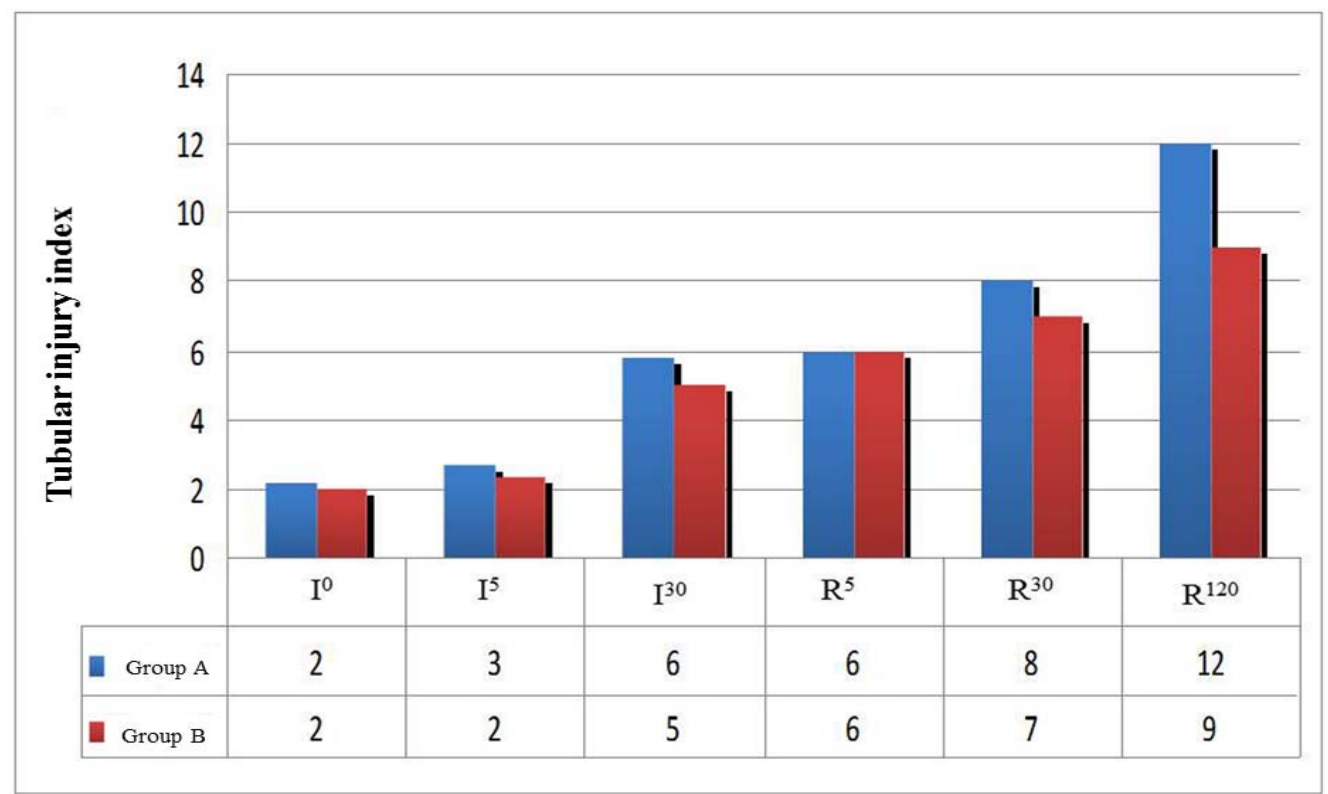

Figure 2. Tubular injury index after renal ischemia and reperfusion in dogs treated (GroupA) or not treated (GroupB) with chlorpromazine. ab - periods with different letters differ statistically by KruskalWallis test $(\mathrm{P}<0,05)$ within the groups. 
The medullary compartment showed staining varying from discrete to intense. $\beta$-catenin was found in a linear pattern at the lateral portion of the plasma membrane in all cortical and medullary structures and in both groups (Figure 3a,b,c,d).

In fragments stained with E-cadherin, staining was positive in all tubular components. However, the experiment showed variation in staining intensity.

(a)

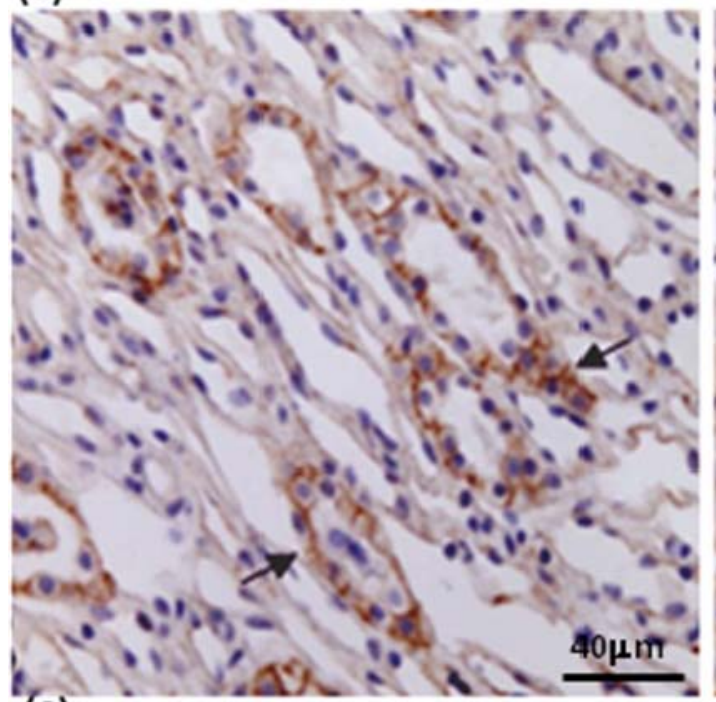

(c)

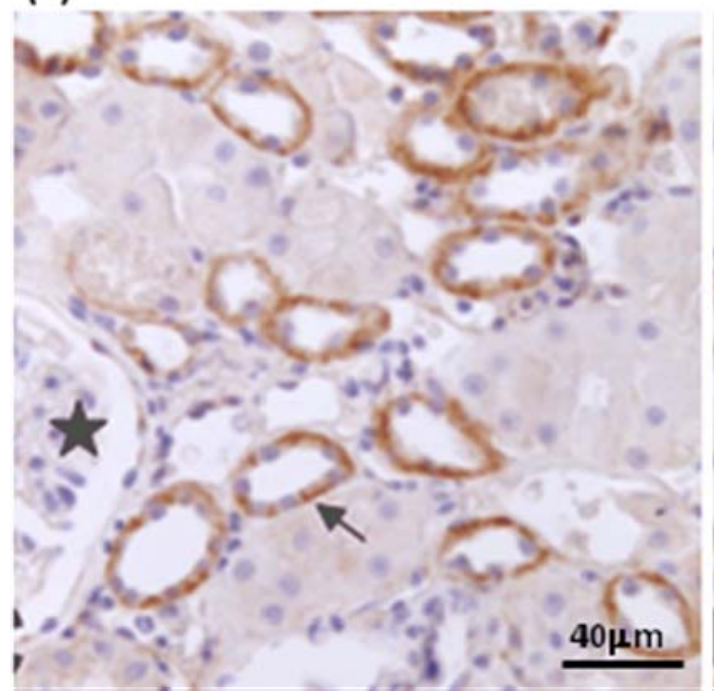

Similarly to $\beta$-catenin, E-cadherin was not expressed in glomeruli. Staining varied from discrete to moderate in PCT. The behavior was similar to that of $\beta$-catenin in DCT, in which samples expressed scores ranging from moderate to intense (Figure 4a, b,c,d). Staining was continuously positive in medullary components, varying from moderate to intense. (b)

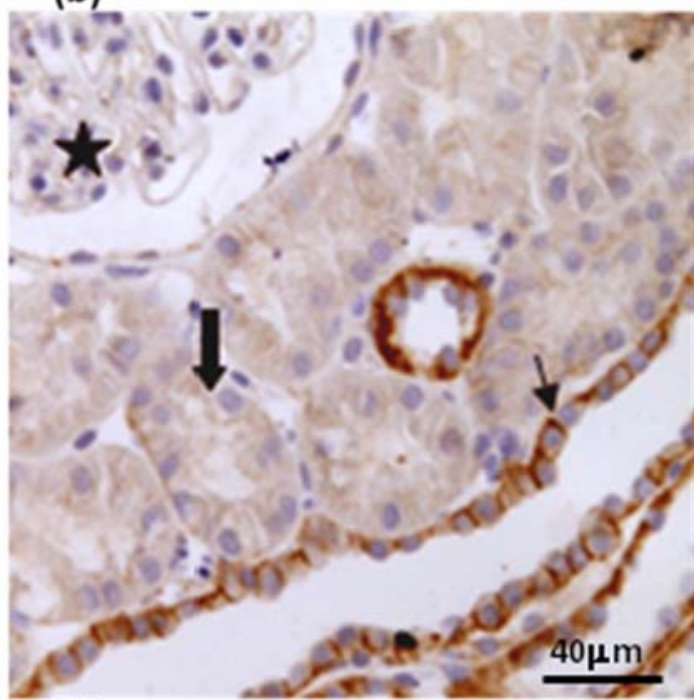

(d)

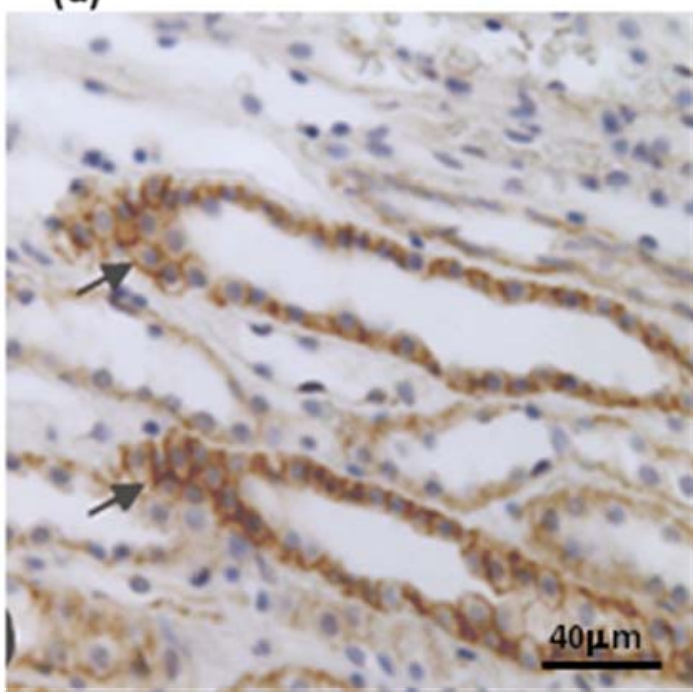

Figure 3. Photomicrographies after renal ischemia and reperfusion injury in dogs stained by antibody anti$\beta$-catenin (scale bars indicated $200 \mu \mathrm{m}$ ), showing the protein in linear form on plasma membrane (arrow), absence of protein in glomeruli (star) and discrete staining in proximal convoluted tubules (block arrow). (a) sample I ${ }^{0}$ of Group A's renal cortex; (b) sample $\mathrm{R}^{120}$ of Group A's renal medulla; (c) sample $\mathrm{I}^{0}$ of Group B's renal cortex; (d) sample $\mathrm{R}^{120}$ of Group B's renal medulla. 
(a)

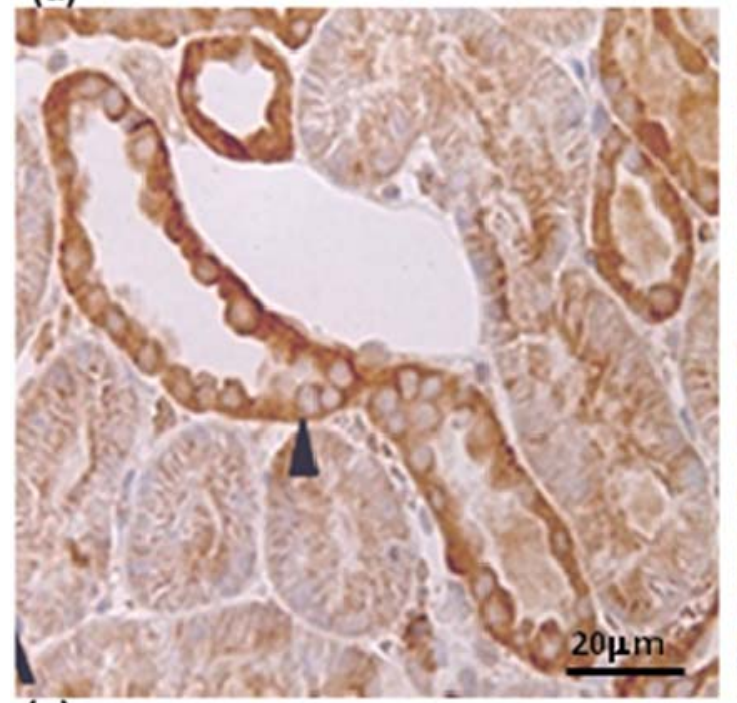

(c)

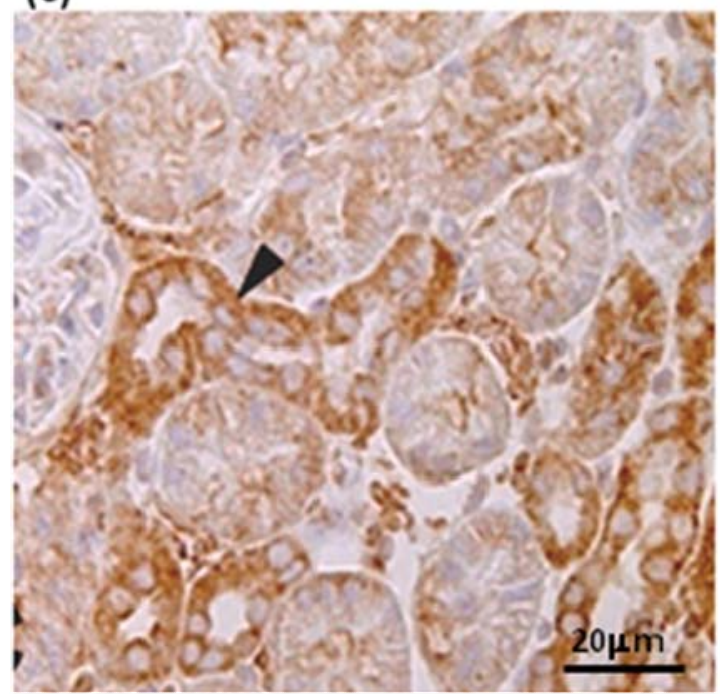

(b)

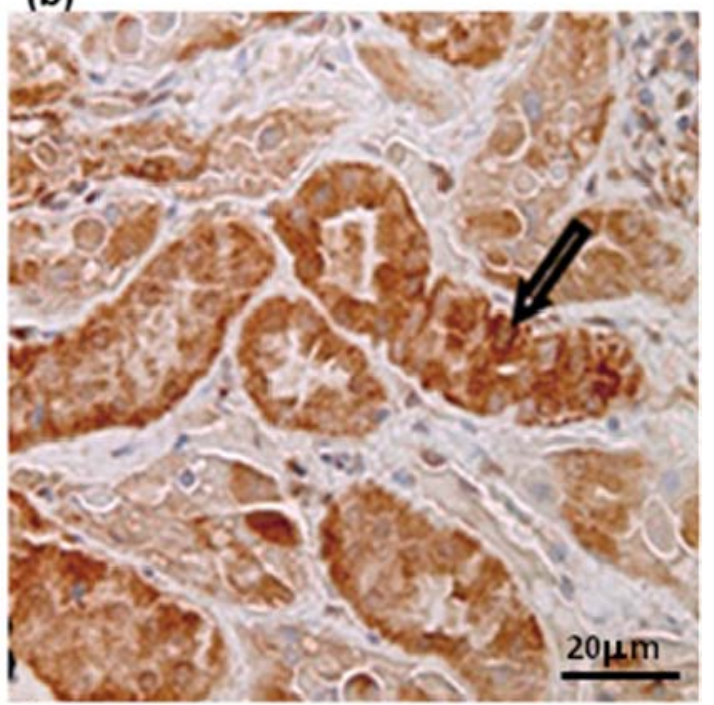

(d)

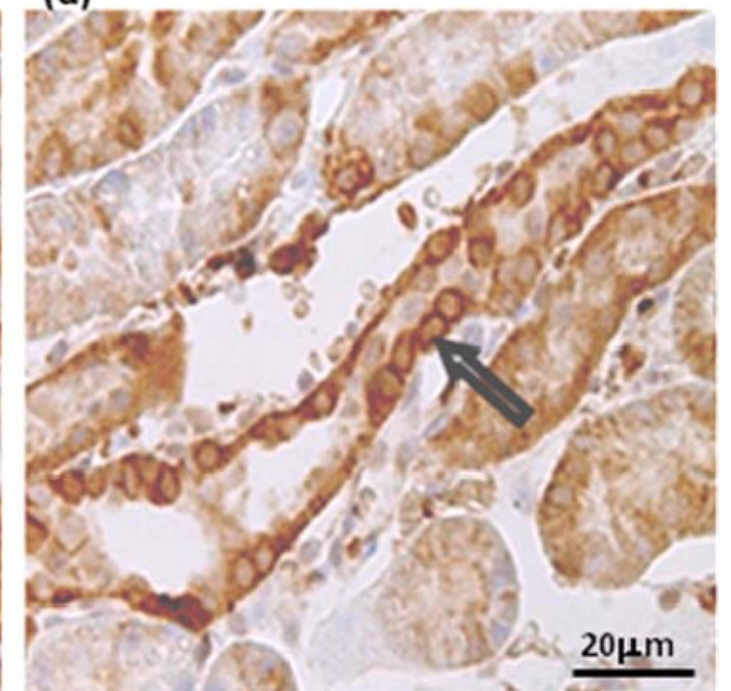

Figure 4. Photomicrography of renal cortex stained by antibody anti-E-cadherin (bar $=400 \mu \mathrm{m})$ after renal ischemia and reperfusion injury in dogs, showing intracytoplasmatic protein (arrow tip) and the protein's relocation in the cytoplasm (open arrow). (a) sample $\mathrm{I}^{0}$ of GroupA's animal; (b) sample $\mathrm{R}^{120}$ of Group A; (c) sample $\mathrm{I}^{0}$ of Group B's animal; (d) sample $\mathrm{R}^{120}$ of Group B.

\section{DISCUSSION}

The most evident changes were desquamation and degeneration, which increased as the injury progressed; such injury was intensified during reperfusion. Researchers have shown that, in 30 min of ischemia, some tubular alterations were aggravated after $30 \mathrm{~min}$ of reperfusion (Chien et al., 1977). The presence of nuclear alterations which point to the irreversibility of tubular injuries, such as picnosis linked to homogeneity and cytoplasmic acidophilia, were discrete even after two hours of reperfusion. Nevertheless, the presence of acute tubular necrosis in renal histopathological examination is seen in occasional tubular cells and even fails to be detected in some cases (Piepenhagen and Nelson, 1998).

This is a pioneering study in reporting information related to E-cadherin and $\beta$-catenin location and expression in canine kidney. Feitosa et al. (2005) showed that a variety of cadherins may be found in the kidney rat, all of which are 
important to the regulation of barrier function and to the stabilization of epithelial polarity. Other studies have reported that changes in expression and function of E-cadherin and $\beta$ catenin may be linked to several processes, such as glomerulonephritis (Netto et al., 2001), renal ischemic injury (Bush et al., 2000a; Prozialeck et al., 2004), and renal neoplasias (Nakopoulou et al., 2002). Therefore, understanding the distribution and specific function of cadherins in the kidney may shed new light on renal function and on the pathophysiology of renal disorders (Balzac et al., 2005).

$\beta$-catenin redistribution was not observed, in view of the fact that ischemia's one and a half hours may not have been enough to induce this change. However, distribution changes in $\beta$ catenin, which was removed from the membrane during hypoxia and a short reoxygenation period but recovered its standard form later on (Bush et al., 2000a). Similarly, there was evident expression of $\beta$-catenin in cytoplasmic and nuclear renal tubules cells, indicating its activation after acute injury kidney induced by folic acid injection and induced by ischemia and reperfusion injury in mice (Prozialeck et al., 2004).

In control samples, E-cadherin was located preferably in the intracytoplasmic region, whereas another researcher referred to the presence of this protein in the plasma membrane as a continuous and linear staining and no more than a discrete intracellular staining (Bush et al., $2000 \mathrm{~b}$ ) and this protein was detected in basolateral plasma membrane domain of tubular epithelial cells in pigs (Lee et al., 2013). Such finding may account for the fact that the antibody used in this study points to E-cadherin's cytoplasmic domain. However, the protein's standard expression was changed in this study, possibly because ischemia causes redistribution of cell surface molecules and cytoskeleton disruption in the short run, but fails to induce the low detection of E-cadherin or of another rapidly degrading molecule (Joeschke, 2003). Furthermore, E-cadherin expression was greater in the medulla than in the cortex in adult pigs kidneys and was not expressed in the glomeruli (Lee et al., 2013).

Chlorpromazine did not interfere with junction proteins' location and expression features in the two groups of animals. According to some researchers, this drug is capable of inhibiting Ecadherin endocytosis and thus of preventing the loss of intercellular contact, an effect not suggested by the present study (Araujo et al., 2002; Sáenz-Morales et al., 2006). However, several studies have used chlorpromazine to protect against ischemia and reperfusion injuries (Joeschke, 2003; Zhou et al., 2012). Redistribution of E-cadherin and $\beta$-catenin has been reported in experimental models of ischemia and reperfusion, but their specific degradation has not (Bush et al., 2000a); this suggests that the lack of differences between the groups in this study may be due to the fact that ischemic injury followed by reperfusion did not determine a drop in junction protein levels.

E-cadherin and $\beta$-catenin have a different expression pattern in cortex and medullary segments in canine kidneys. E-cadherin expression was higher in distal convoluted tubules when compared to proximal convoluted tubules; it was present in all medullary segments and absent in glomeruli. $\beta$-catenin was not expressed in dogs' glomeruli; it was found in very low levels or absent in proximal convoluted tubules, but it was present in loops of Henle and in the collecting duct.

\section{ACKNOWLEDGEMENTS}

The authors thank Antônio Souza da Silva for technical assistance.

\section{FUNDING}

This research received no specific grant from any funding agency in the public, commercial or nonprofit sectors.

\section{REFERENCES}

ARAUJO, W.M.; TUCCI JUNIOR S.; COSTA, R.S. et al. Animal model of ischemic injury, and chlorpromazina protector effect, evaluate by TC99M-MAG3 dynamic renal scan. Acta Circ. Bras., v.17, p.15-19, 2002.

BALZAC, F.; AVOLIO, M.; DEGANI, S. et al. E-cadherin endocytosis regulates the activity of Rap1: a traffic light GTPase at the crossroads between cadherin and integrin function. J. Cell Sci., v.118, p.4765-4783, 2005. 
BUSH, K.T.; KELLER, S.H.; NIGAM, S.K. Genesis and reversal of the ischemic phenotype in epithelial cells. J. Clin. Investig., v.106, p.621626, 2000a.

BUSH, K.T.; TSUKAMOTO, T.; NIGAM, S.K. Selective degradation of E-cadherin and dissolution of E-cadherin-catenin complexes in epithelial ischemia. J. Clin. Investig., v.27, p.847-852, 2000b.

CHIEN, K.R.; ABRAMS, J.; PFAU, R.G. et al. Prevention by chlorpromazine of ischemic liver cell death. Am. J. Pathol., v.88, p.539-553, 1977.

FEITOSA, E.A.N.; TAHA, M.O.; FAGUNDES, D.J. et al. Estudo da morfologia renal após a oclusão da aorta abdominal infra-renal em ratos. Rev. Col. Bras. Cir. v.32, p.178-182, 2005.

HUAN, Y.; ADELSBERG, J.V. Polycystin-1, the PKD1 gene product, is in a complex containing E-cadherin and the catenins. J. Clin. Investig., v.104, p.1459-1468, 1999.

JOESCHKE, H. Molecular mechanisms of hepatic ischemia-reperfusion injury and preconditioning. Am. J. Physiol. Gastrointest. Liver Physiol., v.284, p.15-26, 2003.

LEE, S.; HAN, S.M.; KIM, J. et al. Expression of E-cadherin in pig kidney. J. Vet. Sci., v.14, p.381-386, 2013.

NAKOPOULOU, L.; LAZARIS, A.C.; BOLETIS, I.N. et al. Evaluation of E-cadherin/catenin complex in primary and secondary glomerulonephritis. Am. J. Kidney Dis., v.39, p.469-474, 2002.

NETTO, J.M.B.; TUCCI JR, S.; COLONGNA, A.J. et al. Chlorpromazine and mitochondrial function in kidney ischemia-reperfusion. Acta Cir. Bras., v.16, p.36-40, 2001.
PIEPENHAGEN, P.A.; NELSON W.J. Biogenesis of polarized epithelial cells during kidney development in situ: role of E-cadherinmediated cell-cell adhesion and membrane cytoskeleton organization. Mol. Biol. Cell., v.9, p.3161-3177, 1998.

PROZIALECK, W.C.; LAMAR, P.C.; APPELT, D.M. Differential expression of E-cadherin, Ncadherin and beta-catenin in proximal and distal segments of the rat nephron. BMC Physiol., v.4, p.1-14, 2004.

SÁENZ-MORALES, D.; ESCRIBESE, M.M.; STAMATAKIS, K. et al. Requirements for proximal tubule epithelial cell detachment in response to ischemia: Role of oxidative stress. Exp. Cell Res., v.312, p.3711-3727, 2006.

SCHRIER, R.W.; WANG, W.; POOLE, B. et al. Acute renal failure: definitions, diagnosis, pathogenesis, and therapy. J. Clin. Inves., v.114, p.5-14, 2004.

TAKITO, A.M.; SILVA, J.C.C.B.; BUENO, V. et al. Ischemic and reperfusion syndrome of hind limbs: functional and histological renal changes in rats. Medicina., v.38, p.294-300, 2005.

TSUJ, Y.; ARIYOSHI, A.; SAKAMOTO, K. An experimental model for unilateral ischaemic acute renal failure in dog. Int. Urol. Nephrol., v.25, p.83-88, 1993.

ZHOU, D.; LI, Y.; LIN, L. et al. Tubule-specific ablation of endogenous $\mathrm{B}$ - catenin aggravates acute kidney injury in mice. Kidney Intern. v.82, p.537-547, 2012.

ZUHORN, I.S.; KALICHARAN, D.; ROBILLARD, G.T. et al. Adhesion receptors mediate eficient non-viral gene delivery. Mol. Ther., v.15, p.946-953, 2007. 